\title{
ATYPICAL EVOLUTION AFTER DENGUE: EXTRADURAL HEMATOMA OF VERTEBRAL CANAL LEVEL L4-L5
}

\author{
EVOLUÇÃO ATÍPICA APÓS DENGUE: FORMAÇÃO DE HEMATOMA EXTRADURAL DO CANAL \\ VERTEBRAL NÍVEL L4-L5
}

\section{EVOLUCIÓN ATÍPICA DESPUÉS DEL DENGUE: FORMACIÓN DE HEMATOMA EXTRADURAL DEL CANAL VERTEBRAL NIVEL L4-L5}

\author{
Karoline Alberti, $\mathbb{D}^{1}$ Gustavo Meurer. ${ }^{2}$ Eduardo Valas Schimit, ${ }^{2}$ Odirlei Antonio Magnagnagno ${ }^{3}$ \\ 1. Centro Universitário da Fundação Assis Gurgacz, Degree Program in Medicine, Cascavel, PR, Brazil. \\ 2. Hospital São Lucas, Department of Orthopedics and Traumatology, Cascavel, PR, Brazil. \\ 3. Hospital São Lucas, Department of Hospital Management, Cascavel, PR, Brazil.
}

\begin{abstract}
The objective of this paper is to report a case of atypical evolution after a classic case of dengue confirmed by serology, in which the formation of an epidural hematoma with low back pain and radiculopathy was observed. The article is a qualitative and descriptive case report. Data were collected from the medical records of the hospital where the patient was treated. In conclusion, the diagnostic correlation of dengue with this rare condition was possible due to radiological comparisons before and after the formation of the extradural hematoma. Level of evidence V; Expert Opinion.
\end{abstract}

Keywords: Dengue; Hematoma, Epidural, Spinal; Lumbosacral Region.

\section{RESUMO}

O presente trabalho tem como objetivo relatar um caso de evolução atípica após quadro clássico de dengue, confirmada por sorologia, em que foi obsenvada a formação de um hematoma extradural, com dor lombar baixa e radiculopatia. O artigo é tipo relato de caso, qualitativo e descritivo. Os dados foram coletados no prontuário do hospital onde o doente foi atendido. Como conclusão, a correlação diagnóstica da dengue com essa afecção rara foi possível devido a comparações radiológicas pré- e pós-formação do hematoma extradural. Nível de evidência V; Opinião de Especialista.

Descritores: Dengue; Hematoma Epidural Espinhal; Região Lombossacral.

\section{RESUMEN}

El presente trabajo tiene como objetivo relatar un caso de evolución atípica después de un cuadro clásico de dengue, confirmado por serología, en el que se observó la formación de un hematoma extradural, con dolor lumbar bajo y radiculopatía. El artículo es tipo relato de caso, cualitativo y descriptivo. Los datos fueron recolectados en el prontuario del hospital en donde el enfermo fue atendido. Como conclusión, la correlación diagnóstica del dengue con esta afección fue posible debido a las comparaciones radiológicas pre y post formación del hematoma extradural. Nivel de evidencia V; Opinión de Especialista.

Descriptores: Dengue; Hematoma Espinal Epidural; Región Lumbosacra.

\section{INTRODUCTION}

Today dengue has become a serious public health problem, not only in relation to its incidence, in which there has been a significant increase, but also to the growth of its complications reflected in higher morbidity and mortality rates. ${ }^{1}$

In a study of the medical records of 543 patients infected with type 3 arbovirus in 2007 in Mato Grosso do Sul (BR), the main hematological changes observed in approximately $65 \%$ of the cases were leukopenia, lymphocytopenia, plateletopenia, and the presence of atypical lymphocytes. Bleeding was observed in patients with platelet counts considered low risk for hemorrhage (greater than $50,000 / \mathrm{mm}^{3}$ ), suggesting a relationship between other factors and the bleeding episode, such as platelet dysfunction, coagulation disorders, or vascular impairment. ${ }^{2}$
Spinal epidural hematoma $(\mathrm{SEH})$ is a rare condition with an estimated incidence of $0.1 / 100,000$ inhabitants. $^{3}$

SEHs are mainly asymptomatic, becoming symptomatic when they generate root compression. They present intense, usually sudden pain in the vertebral region, radiating to the lower limbs, also with sensory and motor alterations in their dermatomes resulting from compression of the affected nerve. The clinical course has fluctuating symptoms and the condition requires specific symptomatic treatment. ${ }^{3,4}$

Possible etiologies for SEH include trauma, coagulopathies of various causes, postoperative complications, antiplatelet therapy, arteriovenous malformations, rheumatic conditions, and hemorrhagic disorders. Spontaneous spinal epidural hematomas (SSEH), that is, those with no apparent cause or associated risk factor, account for only $0.3 \%$ to $0.9 \%$ of epidural spinal canal lesions. ${ }^{4,5}$ 


\section{METHODS}

This article was prepared from data held in the archives of the Hospital São Lucas FAG, located in the city of Cascavel - Paraná. In addition, the discussion was based on subject matter articles and the available scientific literature. The research project was submitted to the Institutional Review Board of the Centro Universitário FAG and approved as number CAAE 83785417.1.0000.5219. All the participants signed an informed consent form (ICF) to participate in this article.

\section{CASE REPORT}

A 61-year-old man came to the emergency room reporting that 6 days before he had come in contact with water from the reservoir and the he had had a fever for 4 days, measured at $39^{\circ}$, adynamia, myalgias, retro-orbital pain, abdominal pain, foul smelling urine, lack of appetite, and nausea.

In the physical examination he presented white tongue, pain upon palpation of the right hypochondrium, edema of the lower limbs, and bilateral exanthematic ankle lesions.

A hypothesis of dengue was proposed, due to the endemic contact area, symptomology, and clinical examination, and the conduct adopted was hospitalization, request for complementary tests, and IgG and IgM serology for flavivirus.

Laboratory tests collected on the day of hospitalization: leukocytes $1,730 \mathrm{~mm}^{3}, 0 \%$ blasts, hemoglobin $13.5 \mathrm{~g} / \mathrm{dL}$, hematocrit $41.5 \%$, platelets $38,500 \mathrm{~mm}^{3}$, aspartate aminotransferase (TGO) $64.1 \mathrm{U} / \mathrm{L}$, alanine aminotransferase (TGP) $53.0 \mathrm{U} / \mathrm{L}$, C-reactive protein $18.912 \mathrm{mg} / \mathrm{dL}$, prothrombin activity $80.6 \%$, and INR (international normalized ratio) 1.15.

Positive serology (IgM and IgG) confirmed the diagnosis of dengue. The patient remained in the service for four days under a treatment protocol for dengue with improving symptoms and laboratory test results and was discharged for outpatient follow-up.

Ten days after the onset of symptoms and six days after the last treatment, the patient returned to the hospital reporting low back pain radiating bilaterally to the lower limbs without a specific dermatome.

On physical examination, he had pain upon palpation of the spinous process at lumbar vertebrae levels 2, 3, and 4, cutaneous pallor of the lower limbs, sensory deficit for the entire extension of the lower limbs, and a positive Laségue test at 40 degrees, bilaterally, without associated motor deficit.

The patient was admitted for analgesia and for investigation of the lumbar complaint by magnetic resonance (MR) of the lumbosacral spine.

The lumbosacral spinal MRI, as shown in Figures 1 and 2, produced the following findings:

- Elongated posterior extradural tissue in the interior of the spinal canal at vertebral levels L3 and L5, of elongated fusiform aspect, measuring around $1.4 \times 6.8 \mathrm{~cm}$, presenting intermediate T2 signal and peripheral contrast enhancement

- Lesion occupying around $40 \%$ of the diameter of the spinal canal,
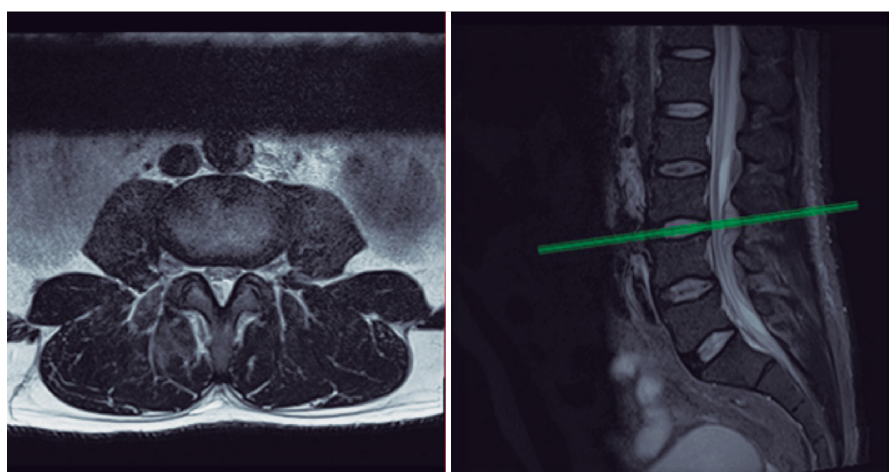

Figure 1. Magnetic resonance of the lumbar spine. displacing the dural sac and descending roots anteriorly and at level L4-L5 appearing to occupy the right side of the spinal canal more than the left.

Among the patient's historical medical records, there was an abdominal CT scan performed at the same service four months prior to the current condition to investigate another complaint, which showed no signs of hematoma formation. (Figure 3) Thus, the magnetic resonance images in Figures 1 and 2, which reveal compression of the spinal canal, permit us to establish a diagnosis of atypical manifestation due to the patient's current disease with the formation of a spinal epidural hematoma.

Conservative treatment was adopted, maintaining symptomatic drug therapy and specific treatment for dengue. In 72 hours, the patient presented significant improvement in low back and radiating pain and was walking without clinical manifestations and without assistance. The laboratory parameters after 15 days showed significant improvement: leukocytes $9,340 \mathrm{~mm}^{3}, 0 \%$ blasts, hemoglobin $12.1 \mathrm{~g} / \mathrm{dL}$, hematocrit $33.5 \%$, platelets $230,600 \mathrm{~mm}^{3}$, TGO 23.2 U/L, TGP 20.9 U/L, C-reactive protein 1.12mg/dL, prothrombin activity $100 \%$, and INR 1.00 .
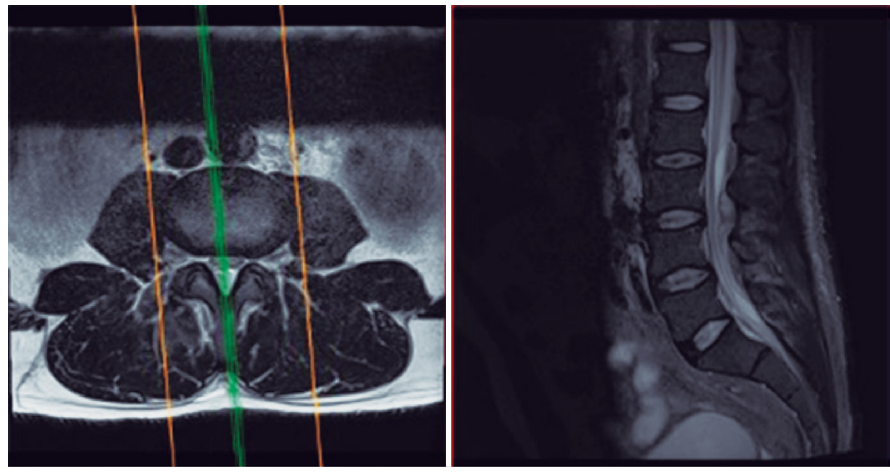

Figure 2. Magnetic resonance of the lumbar spine.
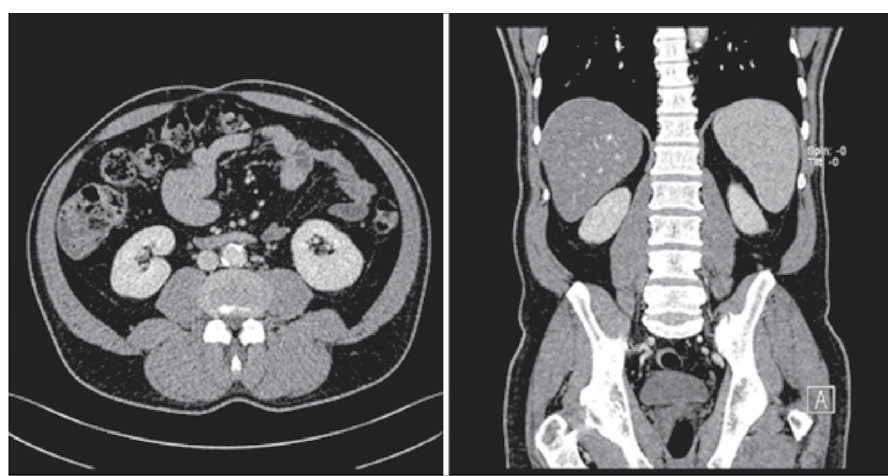

Figure 3. Computed tomography of the abdomen.

\section{DISCUSSION}

Magnetic resonance imaging (MRI) is the method of choice for spinal cord disorders. The choice of treatment, conservative or surgical, is made according to the level of pain and changes in the physical neurological examination. The size of the hematoma cannot be used as a guide for treatment. ${ }^{3,4,6}$

A comparative study of patients with spontaneous spinal epidural hematoma, treated conservatively and surgically, found that in patients submitted to non-surgical treatment, the mean length of the hematoma was significantly greater and the neurological signs and symptoms were less severe than in cases requiring surgery. ${ }^{6}$ No correlation between location of the hematoma, the medical history, sex, or age of the patients and the choice of conservative therapy was established. ${ }^{6}$ This supports the idea that propagation of the hematoma along the length of the spinal peridural space plays a 
role in the decompression of the intradural neural structures and in the subsequent spontaneous relief of the neurological deficit. ${ }^{6}$

The prognosis varies from benign evolutions with spontaneous resolution to conditions of intense pain unresponsive to analgesics to irreversible spinal cord lesions and in order to prevent these, early diagnosis and appropriate treatment are indispensable. ${ }^{3}$

\section{CONCLUSION}

Although infrequent, a suspicion of lumbar spine epidural hematoma should be raised in the presence of symptoms consistent with the condition in patients with dengue so that early diagnosis, adequate therapeutic assessment, and the best prognosis for the patient can occur.

All authors declare no potential conflict of interest related to this article.

CONTRIBUTION OF THE AUTHORS: Each author made significant individual contributions to this manuscript. KA - writing of the text and review of the medical records, responsible for the scientific publication; OM - reviewed the text and provided methodological guidance; GM - writing, provided the clinical case, member of the team responsible for the case reported; EV - writing, member of the team responsible for the case reported.

\section{REFERENCES}

1. Dias LBDA, Almeida SCL, Haes TM, Mota LM, Roriz-Filho JS. Dengue: Transmissão, aspectos clínicos, diagnóstico e tratamento. 2010:43(2):143-52.

2. Oliveira ÉCL, Pontes ERJC, Cunha RV, Fróes ÍB, Nascimento D. Alterações hematológicas em pacientes com dengue. Rev Soc Bras Med Trop. 2009;42(6):682-5

3. Ferreira ACW, Bandeira M, Vieira-Karuta SC, Zeigelboim BS, Jurkiewicz AL, Liberalesso PBN. Hematoma epidural espinal em paciente com lúpus eritematoso sistêmico TT - Spinal epidural hematoma in a patient with systemic lupus erythematosus. Pediatr Mod. 2010;46(6):238-40
4. Chemale IM, Vanzin JR, Pereira Filho A. Hematoma epidural espontâneo: Relato de dois casos. Arq Neuropsiquiatr. 1998;56(3A):453-6.

5. Pasqualini W, Tebet MA, De Carvalho MOP. Hematoma epidural lombar pós-cirurgico em paciente com leucemia. Relato de caso. Coluna/ Columna. 2012;11(3):247-9.

6. Groen RJM, Goffin J. Non-operative treatment of spontaneous spinal epidural hematomas: A review of the literature and a comparison with operative cases. Acta Neurochir (Wien). 2004;146(2):103-10. 